\title{
A mulher em África. Vozes de uma mar- gem sempre presente
}

\author{
Débora Leite DaVID ${ }^{1}$ \\ (Universidade de São Paulo)
}

feminismo em sua concepção primeira de ideologia da igualdade de direitos da mulher em relação ao homem, alcançou incontáveis vitórias ao longo dos séculos XIX e XX, das quais destacamos o direito ao voto, o crescimento das oportunidades de trabalho com melhor remuneração, o direito ao divórcio e o direito ao controle do próprio corpo. Participando cada vez mais dos movimentos revolucionários que se sucederam neste período, as mulheres conquistaram a oportunidade necessária para manifestar suas reivindicações calcadas nas idéias liberais defendidas no espaço revolucionário.

No entanto, é de se notar que para além das iniciativas feministas essencialistas que buscavam a igualdade absoluta entre os gêneros, surgiram pouco a pouco outras vertentes ideológicas no feminino e pelo feminino. Hoje encontramos reflexões pela complementaridade dos gêneros e pela inscrição da mulher na sua diferença. Um abrandamento das palavras de ordem vociferadas nas décadas de 1960 e 1970, que, no entanto, não significou o enfraquecimento dos movimentos sociais e políticos em prol da mulher. Verificamos sim um amadurecimento das múltiplas vozes que rediscutem o papel de cada gênero no âmbito da construção social, em que buscam delinear suas identidades e suas diferenças. A partir dessa complexa dinâmica surgem feminismos variados concebidos em suas múltiplas formas em razão de sua origem fundada em diretrizes sociopolíticas de diferentes grupos, nem sempre formados por mulheres.

Nesse espaço de discussão do feminino e sua realidade no continente africano, destacamos o lançamento de A mulher em Africa. Vozes de uma margem

1 Doutoranda em Estudos Comparados de Literaturas de Língua Portuguesa na Universidade de São Paulo (USP) e bolsista do CNPq. 
sempre presente, compêndio de ensaios organizado por Inocência Mata e Laura Cavalcante Padilha (Lisboa, 2007) e publicado no âmbito da Coleção Tempos e Espaços Africanos da Edições Colibri. Abordando a complexa problemática dos estudos de gênero, esta obra busca dar voz às mulheres na África, com destaque à atuação destas na criação das sociedades e na reinvenção incessante de espaços sociais, econômicos e políticos, marcas indeléveis na História da África.

Reunindo ensaios oriundos de variados campos de conhecimento, A mulher em África traz em estreito diálogo as diferentes perspectivas teóricas que embasam atualmente os estudos de gênero, contemplando, sobretudo, a África sub-saariana, sua realidade histórico-social e a produção de suas escritoras. Percebemos que os trabalhos seguem na direção da conciliação dos gêneros por meio de minuciosa descrição e análise daquilo que cabe a cada parte, mas afastando a exclusão essencialista e aproximando a mistura das diferenças.

Se os historiadores procuram mostrar de que maneira as mulheres africanas ocupam o poder, outros estudiosos as destacam principalmente no campo intelectual - em especial, literário -, espaço também interdito às mulheres durante séculos. Vale destacar que a narratologia africana, em sua grande parte, foi essencialmente masculina, muito em razão da repressão imposta pelas metrópoles na administração colonial, processo que se manteve mesmo com as independências. A literatura espelha essa exclusão que pode ser observada em grande parte dos sistemas literários africanos, com o predomínio de vozes masculinas.

A mulher em África apresenta-se organizado em quatro capítulos, a saber: "O gênero como questão", "Abordagens sócio-históricas", "Mulher e escrita literária", e "Um recorte diaspórico". O primeiro capítulo, "O gênero como questão", é composto pelo ensaio "Por outras formas de Ser e Estar: mulheres, participação e tomada de decisão", de Eunice Macedo e outros. Neste ensaio de abertura são discutidas as questões teóricas do gênero de um modo alargado, sem as amarras de um campo de conhecimento determinado. Com a análise da desigualdade entre homens e mulheres em vários níveis, as ensaístas refletem acerca da problematização das relações de poder e de liderança e dos obstáculos enfrentados pelas mulheres no mundo laboral. De um viés desconstrucionista, as autoras apontam a pluralidade de feminismos e de lugares do feminino como orientação para a identidade feminina que deve ser assumida e de imediato questionada, importando num movimento pela cidadania das mulheres. 
A seguir temos o capítulo "Abordagens sócio-históricas" em que estão coligidos nove ensaios, que abordam temas como a reificação da mulher pelo colonialismo e algumas formas de representação desse processo na tradição oral angolana e na literatura colonial portuguesa; a contribuição das mulheres na construção do saber e do conhecimento, em especial na sociedade angolana; a questão da discriminação na educação; a relação entre desenvolvimento e a auto-estima do sujeito feminino marginalizado, entre outros.

O terceiro capítulo, "Mulher e escrita literária" está subdivido em duas partes. A primeira intitula-se "Sobre a voz autoral feminina" e reúne quatorze ensaios. Os textos aqui coligidos refletem sobre a produção literária de escritoras como Paulina Chiziane, Dina Salústio e Lília Momplé, destacando as questões da guerra, da violência, dos espaços no feminino, do exílio e da criação feminina. A obra de algumas escritoras é retomada em vários artigos, parecendo demonstrar o sucesso das mulheres em adentrar o espaço do poder hegemônico no campo literário.

A segunda parte do terceiro capítulo, "Diálogos pelo feminino", é composta por doze ensaios, que, ainda gravitando pelos mesmos temas da primeira, promove o diálogo das vozes femininas, prevalecendo a produção poética (Ana Paula Tavares, Noémia de Sousa, Alda Lara). Destacamos a presença de textos que focalizam produções autorais masculinas, como é o caso do artigo "Lee-Li Yang, um heterônimo de Virgílio de Lemos", de Ana Mafalda Leite, em que a força do feminino se impõe, não se tolhendo em feminismos e buscando a própria voz. Assim, os diálogos são tecidos pelo feminino e não apenas nele.

O quarto e último capítulo é nomeado "Um recorte diásporico", que é composto pelo ensaio "Oxum: mãe do mundo e nascente da ancestralidade", de Vanda Machado, que aborda um mito africano feminino desde a sua origem religiosa até sua representação na cultura afro-brasileira.

É de se notar nos textos literários a revisão de fatos com a articulação de outros sujeitos através de perspectivas próprias, em que o sujeito feminino está presente na autoria com uma afirmação cada vez mais intensa na produção ficcional, e também na posição de protagonista e sujeito de seu próprio discurso, rompendo com o discurso totalizante do universo masculino.

Essa perspectiva crítica através da escrita, seja pelo feminino ou no feminino, notadamente aquela filtrada nos textos literários produzidos por mulheres, importa no avanço pelo campo da escrita, território de domínio 
essencialmente dos homens. E mais do que tão-somente produção literária, trata-se, outrossim, da consolidação da posição feminina em relação ao campo intelectual, o que implicará em olhares diferenciados até então represados na periferia da intelectualidade e da escrita literária.

Como vemos, trata-se de uma antologia crítica de fôlego que reúne inúmeros estudiosos de variados campos do conhecimento, garantindo a pluralidade de autores e a respectiva diversidade de pontos de vista teóricos presentes nos ensaios coligidos, demonstrando o diálogo cada vez mais intenso firmado no campo da crítica literária sobre a mulher e sua representação na Literatura, para além da problematização das vozes de autoria feminina. 